\title{
Irrigated trap crops impact key hemipteran pests in organic pistachio orchard
}

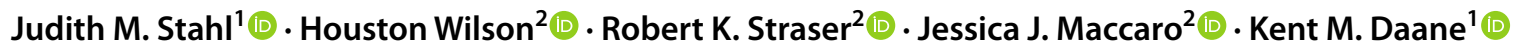

Received: 11 March 2021 / Accepted: 4 September 2021 / Published online: 23 September 2021

(c) The Author(s) 2021

\begin{abstract}
Using sown groundcovers as trap crops to protect a cash crop is a traditional pest management tool. Pistachio is a major crop in California's Central Valley, where high summer temperatures and little to no precipitation between May and November lead to summer dry-down of annual groundcover. Hemipteran pests that consist of 'small bugs' and 'large bugs' are a major contributor to nut damage, especially in organic production. In this 2-year field study, we tested the use of irrigated trap crop mixtures, sown between tree rows, to reduce those hemipteran pests' abundance or damage. Biweekly beat samples of the tree canopy and sweep samples of the sown groundcovers in trap crop plots and resident weedy vegetation in control plots were taken over two consecutive growing seasons. Arthropod richness and abundance were highest in the groundcover and tree canopy in the trap crop plots. Small and large bug pest populations were higher and lower, respectively, in the tree canopy in trap crop plots, indicating a mixed response of these hemipterans to the presence of the trap crops. Additionally, natural enemy populations were more abundant in the tree canopy in trap crop plots than in control plots. There was no difference in nut damage between plots with and without the trap crop. These findings suggest that populations of hemipteran pests and beneficials can be manipulated successfully with irrigated trap crops, but future studies will need to focus on doing so in a way that decreases hemipteran pistachio damage.
\end{abstract}

Keywords Coreidae $\cdot$ Cover crop $\cdot$ Groundcover $\cdot$ Miridae $\cdot$ Lygaeidae $\cdot$ Pentatomidae

\section{Introduction}

The concept of using sown groundcovers as trap crops to protect a cash crop is a traditional pest management strategy (Hokkanen 1991; Thurston 1991; Gurr et al. 2017). The basic requirement for a trap crop system to work is that pests are attracted and migrate to the groundcover for feeding and oviposition (Shelton and Badenez Perez 2006). The trap crop can be used to keep pests out of the cash crop or, if the trap crop does not have inherent qualities that enable them to serve as season-long sinks for the pest species, external

Handling Editor: John F. Tooker.

Judith M. Stahl

judithmstahl@berkeley.edu

1 Department of Environmental Science, Policy, \& Management, University of California Berkeley, Mulford Hall, Berkeley, CA 94720, USA

2 Department of Entomology, University of California, Riverside, CA, USA management options like localized insecticide applications to the trap crop can be employed before the pest species disperses. Conventional trap cropping systems are often used on small-scale farms in developing countries (Khan et al. 2000) but have also found applications in large-scale farming in developed countries (Shelton and Badenez Perez 2006). For example, alfalfa has been successfully used as a trap crop for lygus, Lygus hesperus Knight (Hemiptera: Miridae), in cotton (Godfrey and Leigh 1994), collards for diamondback moth, Plutella xylostella (L.) (Lepidoptera: Plutellidae), in cabbage (Mitchell et al. 2000), and a mustard/pea mix for a stink bug, Nezara viridula (L.) (Hemiptera: Pentatomidae), in sweet corn (Rea et al. 2002).

Groundcovers can facilitate conservation of biological control. They can provide refuge for beneficial arthropods (Carmona et al. 1990; Gillespie et al. 2016), and additional food sources that are either plant-based or by providing alternative prey or hosts (Long et al. 1998; Duyck et al. 2011; Gillespie et al. 2016). For example, nectar of wild mustard (Sinapis arvensis L. [Brassicales: Brassicaceae]) and vetch (Vicia sativa L. [Fabales: Fabaceae]) attracts 
parasitic wasps that are natural enemies of insect pests (Foster and Ruesink 1984; Bugg et al. 1990). Groundcovers can change orchard microclimate: in Chinese citrus orchards, planting or retaining the groundcover Ageratum conyzoides L. (Asterales: Asteraceae) lowers canopy temperature by 5 to $10{ }^{\circ} \mathrm{C}$ and increases relative humidity by more than $5 \%$, creating favorable conditions for Amblyseius sp. (Acari: Mesostigmata) predatory mites that control the citrus red mite Panonychus citri (McGregor) (Acari: Tetranychidae) (Huang et al. 1981).

Pistachio, (Pistachia vera L.), is a major crop in California's Central Valley agriculture (Geisseler and Howarth 2016), with around 160,000 ha and an annual crop value near $\$ 1.7$ billion (USD). The main insect pest in California pistachios is the navel orange-worm, Amyelois transitella (Walker) (Lepidoptera: Pyralidae), but the complex of socalled small and large bugs is also a major contributor to nut damage, especially in organic production (Daane et al. 2005). Small bugs include the Miridae Calocoris norvegicus (Gmelin), Phytocoris relativus Fallén and Lygus hesperus (Knight), the Lygaeidae Nysius raphanus Howard as well as several Rhopalidae (Bentley et al. 2010, 2016). The group of large bugs mainly comprises the stink bugs Chinavia hilaris Say, Thyanta pallidovirens (Stål), Chlorochroa uhleri (Stål) and C. sayi Stål (Hemiptera: Pentatomidae) and the leaffooted bug Leptoglossus zonatus (Dallas) (Hemiptera: Coreidae) (Daane et al. 2016). Small and large bugs feeding on pistachio nuts can result in epicarp lesions, aborted kernels, and increased nut drop (Bostock et al. 1987; Michailides et al. 1987; Purcell 1991). After shell-hardening in the latter half of the season, larger bugs are better able to cause damage by piercing the shell, which can result in necrotic kernels and stigmatomycosis, a fungal infection (Michailides et al. 1987, 1989; Daane et al. 2005, 2016).

Monitoring and control of small and large bugs is a primary Integrated Pest Management (IPM) objective for the pistachio industry. This has become increasingly important as pyrethroids have been a primary control tool for hemipterans but their repeated use targeting moth and hemipteran pests has resulted in resistance development in A. transitella (Demkovitch et al. 2015). As growers replace pyrethroids with other, more narrow-range or sustainable products to combat A. transitella, control of hemipterans using alternative pest management strategies is becoming more important. Herbivorous Pentatomidae and Coreidae are often polyphagous: the four Pentatomidae $C$. hilaris, $C$. uhleri, T. pallidovirens and Euschistus sp. as well as the Coreid $L$. zonatus are pests not only on nut crops such as pistachio and almond (Daane et al. 2005, 2019; da Silva and Daane 2014; Joyce et al. 2019), but are also found on vegetables and row crops such as cotton (Toscano and Stern 1976; Barbour et al. 1990), corn (Jankevicius et al. 1993; Koch et al. 2017), soybean (McPherson et al. 1979; Koch et al. 2017), and tomatoes (Zalom et al. 1997). This makes them a good target for potential management with trap crops.

Trap crops have been used in tree crops in California's Central Valley (Tomaseto et al. 2019), but average high summer temperatures of $37.2{ }^{\circ} \mathrm{C}$ and little to no precipitation between May and November lead to dry-down of annual groundcover during the summer months. This leads to insects migrating from the drying groundcover up into the canopy (da Silva et al. 1997; Wilson et al. 2020a), potentially causing damage at key periods during the season (Stahl et al. 2020). In this study, we propose the use of irrigated trap crops to prevent groundcover dry-down in mid-season. We conducted a 2-year field experiment to determine (1) the seasonal population levels of small and large bug pests and (2) beneficial arthropods known to attack them, (3) if the planting of trap crops reduces feeding damage from those pest groups and (4) the potential of trap crops as a monitoring tool for small and large bug pests in pistachio.

\section{Material and methods}

\section{Experimental design}

The experiments were conducted in a 93-ha commercial organic pistachio orchard that was divided into five replicate blocks (18.6 ha/block) with two plots of 19 rows each (9.3 ha/plot). Paired plots were in a randomized block design with two treatments: trap crop and control, which were around $80 \mathrm{~m}$ apart. The trap crop was a mix of alfalfa (Medicago sativa L.), vetch, and mustard (Brassica sp.) in 2018, and a mix of alfalfa and radish (Raphanus sativus L.) in 2019. These plant species were chosen because of they are readily available to the grower in cover crop mixes and are known host plants of small and large bugs, which makes them prime candidates as trap crops for those pests. In both years, seeds were sown as a $1 \mathrm{~m}$ wide strip in the row middles in the central six rows in each plot in March 2018 and May 2019. The vegetation in the row middles in the control plots consisted of resident weedy vegetation that included Echinochloa crus-galli (L.) (Poales: Poaceae), Euphorbia serpens Kunth (Malpighiales: Euphorbiaceae), Digitaria sanguinalis (L.), Festuca perennis Lam. (Poales: Poaceae), Rumex crispus L. (Caryophyllales: Polygonaceae), Solanum elaeagnifolium Cav., S. nigrum L. (Solanales: Solanales), and Tribulus terrestris L. (Zygophyllales: Zygophyllaceae). The mobile irrigation drip line in the middle of the groundcovers was moved periodically into the tree line (berm) for orchard management. For insect control in 2018, the groundcovers were sprayed with pyrethrin on 12 June and 12 July and mown on 19 June; the canopy was treated with Bacillus thuringiensis, Spinosad and pyrethrin on 14 August. In 2019 , the groundcovers were sprayed with pyrethrin on 12 
July and mown 20 August; the canopy was treated with pyrethrin on 12 May.

\section{Insect sampling}

The pistachio tree canopy was sampled on a biweekly basis to assess the population structure of key pests and beneficials on the target crop. This was carried out by using a PVC pipe to beat branches with pistachio clusters so that insects fell into an insect sweep net, at which point the contents were transferred into 3.8-L plastic zip lock bags. Five subsamples were taken within the six middle rows of each plot. Each subsample consisted of twenty beats, one per tree. Trees were selected haphazardly, with a ten-tree buffer from the edge of the orchard.

To assess the population structure of key pests and beneficials in the groundcover, the ground vegetation was sampled biweekly with sweep nets. Five subsamples were taken within the six middle rows of each plot. Each subsample consisted of thirty sweeps covering the haphazardly chosen area between four trees of two rows, with a ten-tree buffer from the edge of the orchard. In 2019, due to the late sowing and unusually cold weather conditions, the middle section between rows was bare until the end of May. Consequently, the berm within the tree rows was sampled instead until groundcover was present in the row middles. All sampled sections of groundcover for each subsample were ranked in terms of type (95-100\% green, $50-95 \%$ green, $0-50 \%$ green), percent coverage, and phenological stage (percent vegetative, flowering, seeding, and senescing).

In 2019, black hanging panel traps were utilized to monitor Pentatomidae and Coreidae seasonal population levels. Traps were hung on the south side of trees between 1.5 and $2.0 \mathrm{~m}$ from the ground. The middle row of every plot was equipped with five traps, spaced ten trees apart, with a tentree buffer from the edge of the orchard. The traps were emptied, Pentatomidae and Coreidae taken to the laboratory for species identification, and the soapy water of the collecting reservoir exchanged in biweekly intervals. The traps were baited with a mixture of crushed pistachio and almond nuts (Peterson Trap Company LLC, Visalia, USA) that was replaced each month.

\section{Sample processing}

Samples obtained from the canopy and the groundcover were processed similarly: individual subsamples in plastic bags were frozen at $-20^{\circ} \mathrm{C}$ for a maximum of 6 months before processing. Key hemipteran pest and beneficial species were catalogued for each sample. The presence of other insect groups was recorded, but individuals were only counted in 2018. Hemipteran pests and coccinellid beetles were identified to species level, other beneficial insects to family level. Spiders were recorded as predators but not further identified.

\section{Assessment of pistachio damage}

Pistachio clusters were harvested manually around 1 week prior to commercial harvest in September to assess damage in the laboratory separately for trap crop and control plots. In 2018, 400 to 500 nuts per plot were harvested, and in 2019, 2000 to 3500 nuts per plot; totaling 35,000 processed nuts. Pistachios were assessed for damage including epicarp lesions, shell staining, as well as necrotic, aborted, and moldy kernels. During commercial harvest, all control plots were harvested separately from all trap crop plots and both groups underwent commercial damage assessment. Hereby, a $9 \mathrm{~kg}$ subset of pistachios per 18,000 kg truckload was deshelled and dried. Of that subsample, another subsample of $500 \mathrm{~g}$ was graded for damage, where small depressions on the nuts were used to identify damage by large bug feeding.

\section{Statistical analyses}

Results are reported as mean \pm SE. The difference in number of arthropod richness (=number of insect groups, as well as spiders as one group) and abundance (=number of individuals) per sample was compared among locations (trap crop tree canopy, trap crop groundcover, weedy vegetation tree canopy, weedy vegetation groundcover) with a generalized linear mixed model (GLMM) with a Poisson error distribution using location as a fixed effect and replicate block as a random effect. Similarly, the influence of the groundcover on arthropod populations were individually analyzed for each target group (small bugs, large bugs, predators, parasitoids). Model assumptions were checked using Q-Q plots (normality of variance) and by plotting residuals against fitted values (homogeneity of variance). Post-hoc pairwise comparisons were conducted with Tukey multiple comparisons tests. Results of the Tukey tests are recorded as uppercase letters after the mean \pm SE; results sharing a letter are not significantly different.

Laboratory-assessed pistachio damage was analyzed with a generalized linear model (GLM) with a binomial error distribution using treatment (trap crop, control) as fixed effect for each dependent variable (proportion of nuts with damage, proportion of nuts with epicarp lesion, shell staining, kernel necrosis, aborted kernels, moldy kernels). In case of over-dispersed data, a quasibinomial error distribution was assumed. We used backward simplification to generate models containing only significant fixed effect factors and their interactions.

To assess the potential of using sweep samples of the groundcovers as an indication for arthropod populations in 
the pistachio canopy, a Pearson's product-moment correlation was run for each target group separately. Hereby, mean numbers of arthropod per replicate block in the groundcovers were analyzed for correlation with mean numbers of arthropods per replicate block in the canopy.

All statistics were run with $\mathrm{R}$ version 3.6.2 ( $\mathrm{R}$ Core Team 2020) using RStudio version 1.2.5033 (RStudio Team 2016). Packages used included 'Ime4' (Bates et al. 2015) and 'car' (Fox et al. 2016) for the GLMM, as well as 'multcomp' (Hothorn et al. 2017), 'multcompView' (Graves et al. 2019) and 'emmeans' (Length 2020) for Tukey multiple comparisons.

\section{Results}

In total, more than 66,000 arthropods were processed and sorted into more than 60 species (for small and large bugs) or families (for most predators and parasitoids). Small bugs $N$. raphanus and L. hesperus were the most abundant species of interest with 15,472 and 7765 individuals, respectively. Minute pirate bugs Orius spp. Wolff (Hemiptera: Anthocoridae) and spiders followed as the most abundant predators with 3414 and 2774 individuals, respectively. Large bugs were present in smaller numbers, with $C$. uhleri (642 individuals), C. hilaris (456 individuals), T. pallidovirens (278 individuals) and $L$. zonatus (246 individuals) as the main contributors. The group of large bugs was comprised of eight species, and there were five species of small hemipteran pests (Table 1).

Both sown trap crops and the resident weeds in the control plots provided green (= sampled plots $50-100 \%$ green) ground coverage between the end of May and the beginning of August in 2018, which is when sampling ended that year, and until mow-down before harvest in mid-September 2019. In most plots, groundcovers were flowering around June and seeding in July and August.

There were significant differences between locations (trap crop-tree canopy, trap crop-groundcover, weedy vegetation - tree canopy, weedy vegetation-groundcover) in terms of arthropod richness (= species or families) (Poisson GLMM, $\left.\mathrm{df}=3, \chi^{2}=1719.2, p<0.001\right)$ and abundance $\left(\chi^{2}=39,303, p<0.001\right)$. Both richness and abundance were higher in the trap crop groundcovers than in the control groundcovers, and higher in the tree canopy of the trap crop plots than in the plots with weedy vegetation (Table 2).

Overall, small bugs were the group with the most individuals recovered. They were overwhelmingly located in the groundcovers, both in the trap crop and resident weedy vegetation, but more small bugs were caught in tree canopies with the trap crops as groundcover than in control plots (Tukey pairwise comparison $p<0.001$ ) (Fig. 1). Large bugs were more evenly distributed among the four locations, but there were differences (Poisson GLMM, $\mathrm{df}=1,1995$, $\left.\chi^{2}=125.14, p<0.001\right)$ : more large bugs were present in the trap crop groundcover than in the control groundcover (Tukey pairwise comparison $p<0.001$ ), but this trend was reversed in the canopy with lower numbers in the canopy with trap crop groundcovers (Tukey pairwise comparison $p<0.001$ ) (Fig. 1). Predators and parasitoids were more often found on the groundcovers than in the tree canopy, and both sweep and beat samples recorded more beneficials in the trap crop plots specifically (Fig. 1).

Small bugs were mainly present between May and July (Fig. 2a1 and a2). While large bugs were found in May, populations did not peak until July, and sampling until shortly after harvest in 2019 revealed large numbers late in the season (Fig. 2b1 and b2). Predators were present throughout the season with highest numbers between June and August (Fig. 2c1 and c2). Parasitoids were most numerous early to mid-season and populations dropped sharply afterwards (Fig. 2d1 and d2).

Hanging panel trap catches in 2019 were overall low when compared to population densities measured with beat and sweep samples. All major large bug species were captured with the panel traps, especially $C$. hilaris and $C$. uhleri were abundant in the traps during their peak towards the end of July/beginning of August (SI 1). The first L. zonatus individuals were caught in the panel traps 1 month before they appeared in the beat or sweep samples.

The pistachio damage assessment in the laboratory yielded no differences between trap crop and control plots in terms of overall damage (quasibinomial GLM, $d f=1,17$, $F=0.763, p=0.394$ ), proportion of nuts with epicarp lesion (binomial GLM, $d f=1,17, \chi^{2}=0.00850, p=0.927$ ), stained shell $\left(\chi^{2}=0.140, p=0.708\right)$, necrotic kernel $\left(\chi^{2}=0.262\right.$, $p=0.609)$, aborted kernel $(F=0.184, p=0.673)$, or moldy kernel $(F=0.739, p=0.4013)$.

There was no correlation between sweep and beat samples (Pearson's product-moment correlation, $d f=188$ ) for large bugs $(t=0.766, p=0.445)$, predators $(t=1.798$, $p=0.0738)$, and parasitoids $(t=-0.0117, p=0.992)$, and only a very weak correlation for small bugs $(t=1.993$, $p=0.0478$, cor $=0.144$ ) when groundcovers were analyzed combined. When trap crop groundcovers were analyzed separately, there was a weak correlation between ground and canopy populations for predators $(d f=94, t=2.415$, $p=0.0177$, cor $=0.242)$, but not for small bugs $(t=1.935$, $p=0.0561)$, large bugs $(t=-0.262, p=0.794)$, or parasitoids $(t=-0.277, p=0.783)$.

\section{Discussion}

The tree canopy in plots with trap crops hosted a higher density of small bug and a lower density of large bug pests than the tree canopy in control plots with resident weed 
Table 1 Arthropods per sample in 2018 and 2019 sorted by abundance within target group presented as mean \pm SE

\begin{tabular}{|c|c|c|c|}
\hline Target group & Species or family & 2018 & 2019 \\
\hline \multirow[t]{4}{*}{ Small bug pest } & Nysius raphanus Howard (Lygaeidae) & $9.406 \pm 3.478$ & $2.164 \pm 3.007$ \\
\hline & Lygus hesperus (Knight) (Miridae) & $4.224 \pm 0.470$ & $1.293 \pm 1.665$ \\
\hline & Phytocoris spp. Fallén (Miridae) & $0.016 \pm 0.004$ & $0.027 \pm 0.019$ \\
\hline & Calocoris norvegicus (Gmelin) (Miridae) & $0.008 \pm 0.007$ & $0.003 \pm 0.003$ \\
\hline \multirow[t]{10}{*}{ Large bug pest } & Chlorochroa uhleri (Stål) (Pentatomidae) & $0.391 \pm 0.059$ & $0.094 \pm 0.069$ \\
\hline & Chinavia hilaris Say (Pentatomidae) & $0.048 \pm 0.009$ & $0.137 \pm 0.173$ \\
\hline & Thyanta pallidovirens (Stål) (Pentatomidae) & $0.059 \pm 0.018$ & $0.087 \pm 0.115$ \\
\hline & Leptoglossus zonatus (Dallas) (Coreidae) & $0.004 \pm 0.002$ & $0.096 \pm 0.140$ \\
\hline & Euschistus sp. Uhler (Pentatomidae) & $0.007 \pm 0.003$ & $0.020 \pm 0.014$ \\
\hline & Bagrada hilaris (Burmeister) (Pentatomidae) & $0.006 \pm 0.005$ & $0.000 \pm 0.000$ \\
\hline & Chlorochroa sayi Stål (Pentatomidae) & $0.000 \pm 0.000$ & $0.004 \pm 0.004$ \\
\hline & Holcostethus abbreviates Uhler (Pentatomidae) & $0.001 \pm 0.001$ & $0.001 \pm 0.001$ \\
\hline & Murgantia histrionica (Hahn) (Pentatomidae) & $0.000 \pm 0.000$ & $0.001 \pm 0.001$ \\
\hline & Nezara viridula (L.) (Pentatomidae) & $0.001 \pm 0.001$ & $0.000 \pm 0.000$ \\
\hline \multirow[t]{12}{*}{ Predator } & Anthocoridae & $1.441 \pm 0.200$ & $0.818 \pm 1.073$ \\
\hline & Aranae & $0.642 \pm 0.039$ & $1.897 \pm 1.894$ \\
\hline & Nabidae & $0.373 \pm 0.041$ & $0.346 \pm 0.298$ \\
\hline & Reduviidae & $0.218 \pm 0.025$ & $0.449 \pm 0.318$ \\
\hline & Geocoridae & $0.210 \pm 0.030$ & $0.029 \pm 0.269$ \\
\hline & Chrysopidae & $0.072 \pm 0.007$ & $0.085 \pm 0.066$ \\
\hline & Hippodamia convergens Guérin-Méneville (Coccinellidae) & $0.042 \pm 0.012$ & $0.090 \pm 0.020$ \\
\hline & Brochymena sulcate Van Duzee (Pentatomidae) & $0.028 \pm 0.005$ & $0.009 \pm 0.009$ \\
\hline & Syrphidae & NA & $0.019 \pm 0.020$ \\
\hline & Coccinella septempunctata (L.) (Coccinellidae) & NA & $0.003 \pm 0.003$ \\
\hline & Mantidae & $0.000 \pm 0.000$ & $0.002 \pm 0.003$ \\
\hline & Coccinellid larvae & NA & $0.001 \pm 0.001$ \\
\hline \multirow[t]{6}{*}{ Parasitoid } & Hymenopteran parasitoids & $0.353 \pm 0.047$ & $0.475 \pm 0.533$ \\
\hline & Ichneumonidae & $0.007 \pm 0.003$ & $0.030 \pm 0.030$ \\
\hline & Scelionidae & $0.006 \pm 0.003$ & $0.038 \pm 0.039$ \\
\hline & Pteromalidae & NA & $0.072 \pm 0.072$ \\
\hline & Bethylidae & NA & $0.028 \pm 0.028$ \\
\hline & Trichopoda pennipes (Fabricius) (Tachinidae) & NA & $0.001 \pm 0.001$ \\
\hline \multirow[t]{2}{*}{ Other beneficial insects } & Wild bees & $0.040 \pm 0.008$ & $0.024 \pm 0.024$ \\
\hline & Apis mellifera L. (Apidae) & $0.000 \pm 0.000$ & $0.005 \pm 0.006$ \\
\hline
\end{tabular}

Table 2 Arthropod richness and abundance groups and individuals per location as mean $\pm \mathrm{SE}$

\begin{tabular}{llc}
\hline Location & $\begin{array}{l}\text { Richness } \\
\text { (groups per } \\
\text { sample) }\end{array}$ & $\begin{array}{l}\text { Abundance } \\
\text { (individuals per } \\
\text { sample) }\end{array}$ \\
\hline Trap Crop-Tree Canopy & $3.25 \pm 0.12^{\mathrm{c}}$ & $8.67 \pm 0.58^{\mathrm{c}}$ \\
$\begin{array}{l}\text { Trap Crop-Groundcover } \\
\text { Weedy Vegetation-Tree Canopy }\end{array}$ & $\begin{array}{l}7.98 \pm 0.24^{\mathrm{a}} \\
\text { Weedy Vegetation-Ground- }\end{array}$ & $5.70 \pm 0.10 \pm 12.57^{\mathrm{a}}$ \\
\begin{tabular}{l} 
cover \\
\hline
\end{tabular} & $5.35 \pm 0.41^{\mathrm{d}}$ \\
\end{tabular}

Means were compared between locations separately for groups and individuals. Means sharing a letter are not significantly different (Tukey multiple comparisons test $\alpha>0.05$ ) vegetation. There were similar numbers of large bugs in the treatment and the control plots, but the insects were retained more by the trap crops than by the weedy groundcovers. Both predators and parasitoids were most abundant in the trap crops, and it translated into increased beneficial numbers in the tree canopy in these plots.

Hemipteran pests relevant to California pistachio production oftentimes overwinter outside the orchards and adults can colonize the orchard in the spring, causing significant crop damage (Daane et al. 2016). Management strategies could therefore focus on preventing this pest influx in spring, for example by planting trap crops around the orchards as demonstrated in other crop systems (Hokkanen 1991; Soergel et al. 2015; Majumdar and Price 2019). However, 
Fig. 1 Summary of sweep and beat sample catches of target arthropod groups over 2 years. Treatments were compared within target group. Different letters indicate significant differences (generalized linear mixed model [GLMM], Tukey adjusted mean separations)

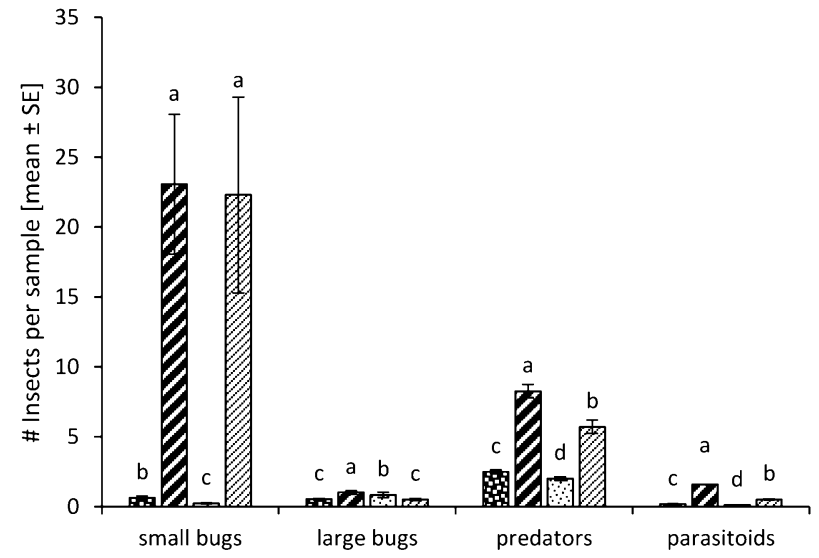

Firap Crop - Tree Canopy

NTrap Crop - Groundcover

Weedy Vegetation - Tree Canopy

W Weedy Vegetation - Groundcover

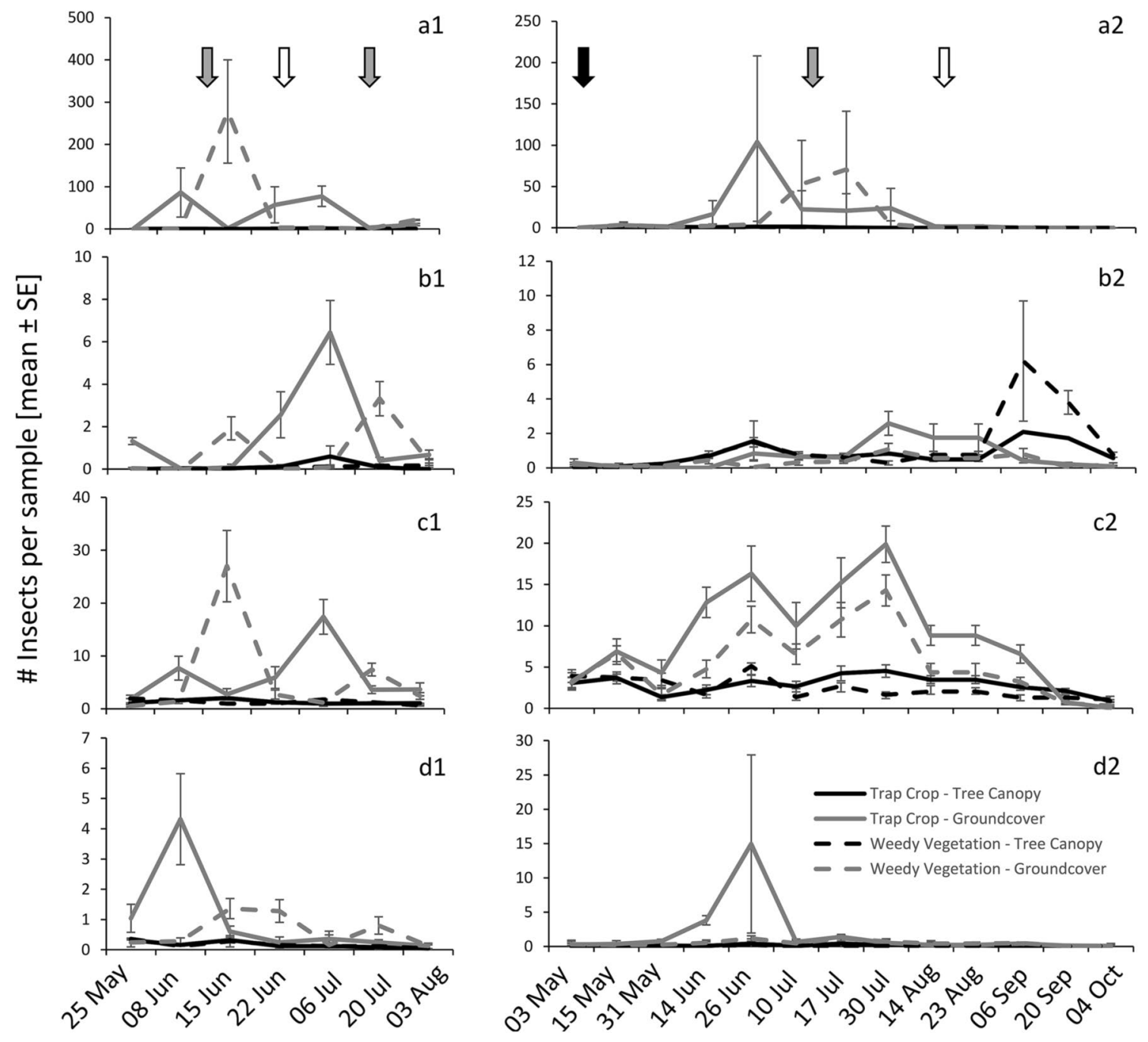

Fig. 2 Sweep and beat sample catches of small bugs (a), large bugs (b), predators (c), and parasitoids (d) in 2018 (1) and 2019 (2). Arrows on the top indicate insecticide treatment with pyrethrin of the trap crop groundcover (grey) or the tree canopy (black), and mowing of the groundcover (white) 
pistachio orchards themselves also serve as overwintering habitat for both small and large bugs (Holtz 2002; Daane et al. 2016), which may make planting the trap crops inside the orchard, as in this current study, more viable.

Small bugs were most abundant in the earlier half of the season, which follows similar studies (Michailides et al. 1987; Purcell 1991). While early-season nut feeding by small bugs can cause epicarp lesions (Michailides et al. 1987), the pistachio trees can often compensate for early-season damage via nut drop (Daane et al. 2005). Consequently, small bugs are likely to be a lesser source of nut damage in this type of orchard. In contrast, large bugs can cause nut damage until harvest in the fall (Michailides et al. 1987; Daane et al. 2005; Stahl et al. 2020) and here were more abundant in the latter half of the season, confirming previous observations in California pistachio orchards (Michailides et al. 1987; Daane et al. 2005). Large bugs generally feed on all plant tissues but prefer reproductive structures (Acebes-Doria et al. 2016). Consequently, they tend to migrate among host plants, following plant phenology (Todd 1989; Velasco and Walter 1993). In California, pistachio trees flower in April and hold nuts until harvest in September (Kallsen et al. 2009), presenting attractive structures for the whole season. To successfully act as trap crops, groundcovers need to present a more attractive target. In this study, both weedy vegetation and trap crops were in reproductive stages between June and August, which is when large bug populations were greatest. The abundance of large bugs on the sown trap crops might be an indication that they successfully attracted and retained large bug pests in the groundcover.

Overall, there was higher arthropod richness and abundance in the groundcovers than in the tree canopy, potentially also a result of the irrigation providing green groundcover until the end of the season, which is abnormal in this region where most groundcover dry down in May. Groundcovers, especially planted annual and perennial groundcovers, can facilitate biological control (Altieri and Letourneau 1982). The addition of these groundcovers complexifies the habitat by increasing plant diversity, which leads to higher arthropod diversity (Pacheco and Vasconcelos 2012; Adhikari and Menalled 2020) as observed in this current study. The increased stability of the ecosystem often results in better biological control and reduces pest outbreaks (Marino and Landis 1996; Langellotto and Denno 2004). Abundance of beneficial arthropods was positively influenced by the trap crops, as more predators and parasitoids were found in the groundcover and canopy of plots containing sown groundcovers strips than in plots with weedy vegetation. Generalist predators like spiders (Morrison et al. 2016, 2017; Abram et al. 2017), Coccinellidae, Nabidae, Reduviidae and predatory Pentatomidae (Pote and Nielsen 2017) as well as parasitoids in the Tachinidae (Abram et al. 2017) and more specific egg parasitoids (Tillman 2011; Abram et al. 2017) are known to attack large bug pests. These arthropods recorded as beneficial based on their potential to attack hemipteran pests, and we did observe large bug eggs being successfully attacked by scelionid parasitoids, however, we did not measure if this increase in beneficials led to increased predation or parasitism.

This first trial with alfalfa, mustard, vetch, and radish as annual summer trap crops in organic pistachios did not lead to increased nut damage. Laboratory assessment of harvested pistachios showed no difference in damage between nuts in the trap crop plots and weedy control plots. In addition to the laboratory assessment, treatment and control plots were harvested separately and assessed commercially in two separate groups in both years of the experiment. In 2018, no differences could be detected, but in 2019 nuts grown in treatment plots were half as likely to exhibit signs of hemipteran damage as those in control plots. This could indicate an effect of the trap crop treatment, but without replication this cannot be confirmed. It also poses the question if there was a differential impact of the two plant species mixtures used over the two growing seasons. With the current experimental design, no conclusions for the specific trap crops involved can be drawn. However, since we proved that populations of hemipteran pests and beneficials can be manipulated with the trap crops, this study provides the foundation for future studies investigating different trap crop species and management strategies to ultimately reduce nut damage, providing a return for the costs of seed (in this case around USD 25 per hectare) and labor introduced into the system with the addition of sown groundcover strips.

To successfully control insect pests, trap crops need to function as sinks (Badenes-Perez et al. 2014) or they need to be managed to avoid serving as alternative food and reproduction sites (Tomaseto et al. 2019). Aside from insecticide applications, cultural tactics like mowing the groundcovers can be applied (Stern et al. 1964; Hokkanen 1991; Godfrey and Leigh 1994; Mensah and Khan 1997). In this experiment, the tree canopy and trap crops were treated with insecticides and the groundcover was mowed. Overall, little effect on hemipteran pest populations was recorded, but there seem to have been impacts on individual species: in 2018, populations of the small bugs $N$. raphanus, L. hesperus and the large bugs T. pallidovirens and $C$. hilaris seemed to decrease after treating the trap crop with pyrethrin and mowing, but the two large bug species seemed to have migrated to the canopy instead; in 2019 L. hesperus and C. uhleri populations were reduced on the trap crop after it was sprayed, and since sampling continued until the beginning of October, the impact of mowing groundcovers before harvest in August/September became apparent. Results indicated that large bugs, especially $C$. hilaris and $C$. uhleri moved to the canopy around harvest time. This suggests that, despite pyrethrin being a 
standard insecticide against stink bugs in organic agriculture (Kamminga et al. 2009; Morehead and Kuhar 2017), hemipteran pest species react differently to management practices and control measures need to be refined to reduce populations in the canopy of most, if not all, hemipteran pests. There were no visible effects of mowing on the complex of beneficial insects and spraying the trap crops with pyrethrin had mixed results: after the 2018 sprays fewer predators seemed to have been recovered from the treated plots, confirming the moderate toxicity of this active ingredient against natural enemies. For parasitoids this was also the case after the first spray, but in the latter half of the season parasitoid abundance was too low to see an effect. In 2019, the pyrethrin spray of the trap crop groundcover did not seem to affect predator population density in the treated plots, and parasitoid abundance had already dropped shortly before the application. The 2019 early season tree canopy application with pyrethrin did not have a visible impact on beneficial insects. Pyrethrin has been shown to cause deleterious effects on natural enemies such as stink bug egg parasitoids but seems to be less harmful than another organic insecticide, Spinosad (Ogburn and Walgenbach 2019; Ribeiro et al. 2021). This mixed response of predators and parasitoids could be influenced by pyrethrin's low persistence and its repellent effect. It highlights the complex issues of integrating different pest management strategies, underscoring the need for studies investigating the intersection of biological, chemical and cultural control.

Monitoring is an essential component of Hemiptera pest control in pistachio production. Usually, large bug monitoring is based on beat samples of the tree canopy or trapping. There are a large variety of traps available (Morrison et al. 2015) and accompanying pheromone lures for many species (Borges et al. 1998; Tillman et al. 2010; Khrimian et al. 2014), but beat samples are considered to be the most accurate to determine pest presence in the pistachio canopy (Daane et al. 2016). Since beat samples of the tree canopy are time-intensive and can underestimate abundance of flying insects, we wanted to test if sweeping the groundcovers, the best sampling method to determine if hemipteran pests are in the orchard (Daane et al. 2016), could be an appropriate substitute. Our results indicate that taking sweep samples from the trap crops is not an accurate monitoring tool since there was little to no correlation between beat and sweep samples. Similarly, there was a correlation between stink bug catches with baited pyramid traps and tree beating in apple, but less with sweep netting and none with either sampling technique in peach orchards (Leskey and Hogmire 2005). The black hanging panel traps without pheromone lures caught all major large bug species recovered with beat and sweep samples, but underestimated population density. Since $L$. zonatus were caught in the panel traps weeks before they appeared in other samples, the traps remain a promising tool for L. zonatus monitoring once an appropriate lure is developed (Wilson et al. 2020b).

This 2-year field study showed that sowing trap crops in between pistachio tree rows has the potential to reduce large bug pest populations while increasing beneficial arthropods populations. Future studies should confirm the results in other sites and explore the use of other trap crop species with the goal to reduce nut damage caused by hemipteran pests. If this can be achieved, trap crops could be implemented into the IPM strategy for California nut production.

Supplementary Information The online version contains supplementary material available at https://doi.org/10.1007/s11829-021-09869-7.

Acknowledgements The authors are grateful to Tyler Colombero, Gabrielle Celaya, Javier Herrera, Danielle Evans, Sunny Yang, Garrett Morales, Alonzo Ledesma, Ethan Ramos, Thomas De Schepper, German Camacho, Reva Scheibner, Lino Salinas, Abraham Mendez, and Victoria Morelos for technical assistance and thank James Nichols for his initiative and providing the orchard.

Author contribution Conceptualization: KMD and HW; methodology: KMD and HW; formal analysis: JMS; investigation: JJM, JMS, RS; writing—draft preparation: JMS; writing—review and editing: HW, RS, JJM, KMD; visualization: JMS; supervision: KMD and HW; project administration: JJM and JMS; funding acquisition: KMD and HW. All authors have read and agreed to the published version of the manuscript.

Funding This project received funding from the California Pistachio Research Board No. ENT-2019-003, California Department of Food and Agriculture's Specialist Crop Block Grant No. 19-0001041-SF, and the USDA's Specialty Crop Research Initiative No. 2016-51181-25409.

\section{Declarations}

Conflict of interest The authors declare no conflicts of interest.

Open Access This article is licensed under a Creative Commons Attribution 4.0 International License, which permits use, sharing, adaptation, distribution and reproduction in any medium or format, as long as you give appropriate credit to the original author(s) and the source, provide a link to the Creative Commons licence, and indicate if changes were made. The images or other third party material in this article are included in the article's Creative Commons licence, unless indicated otherwise in a credit line to the material. If material is not included in the article's Creative Commons licence and your intended use is not permitted by statutory regulation or exceeds the permitted use, you will need to obtain permission directly from the copyright holder. To view a copy of this licence, visit http://creativecommons.org/licenses/by/4.0/.

\section{References}

Abram PK, Hoelmer KA, Acebes-Doria A, Andrews H, Beers EH et al (2017) Indigenous arthropod natural enemies of the invasive 
brown marmorated stink bug in North America and Europe. J Pest Sci 90:1009-1020. https://doi.org/10.1007/s10340-017-0891-7

Acebes-Doria AL, Leskey TC, Bergh JC (2016) Host plant effects on Halyomorpha halys (Hemiptera: Pentatomidae) nymphal development and survivorship. Environ Entomol 45:663-670. https://doi. org/10.1093/ee/nvw018

Adhikari S, Menalled FD (2020) Supporting beneficial insects for agricultural sustainability: the role of livestock-integrated organic and cover cropping to enhance ground beetle (Carabidae) communities. Agron 10:1210-1225. https://doi.org/10.3390/agronomy10 081210

Altieri MA, Letourneau DK (1982) Vegetation management and biological control in agroecosystems. Crop Prot 1:405-430. https:// doi.org/10.1016/0261-2194(82)90023-0

Badenes-Perez FR, Reichelt M, Gershenzon J, Heckel DG (2014) Using plant chemistry and insect preference to study the potential of Barbarea (Brassicaceae) as a dead-end trap crop for diamondback moth (Lepidoptera: Plutellidae). Phytochemistry 98:137144. https://doi.org/10.1016/j.phytochem.2013.11.009

Barbour KS, Bradley JR, Bacheler JS (1990) Reduction in yield and quality of cotton damaged by green stink bug (Hemiptera: Pentatomidae). J Econ Entomol 83:842-845. https://doi.org/10.1093/ jee/83.3.842

Bates D, Mächler M, Bolker B, Walker S (2015) Fitting linear mixedeffects models using lme4. J Stat Softw 67:1-48. https://doi.org/ 10.18637/jss.v067.i01

Bentley WJ, Beede RH, Daane KM, and Haviland DR (2010) UC IPM pest management guidelines: Pistachio. University of California Agriculture and Natural Resources Publication no. 21452, Oakland, pp 48-61

Bentley WJ, Goodell PB, Beede RH (2016) Small bugs: neurocolpus, phytocoris, calocoris, and lygus. In: Ferguson L, Haviland DR (eds.) Pistachio production manual. University of California, Agriculture and Natural Resources Publication no. 3545, Oakland, pp 215-224

Borges M, Schmidt FGV, Sujii ER, Medeiros MA, Mori K, Zarbin PHG, Ferreira JTB (1998) Field responses of stink bugs to the natural and synthetic pheromone of the Neotropical brown stink bug, Euschistus heros (Heteroptera: Pentatomidae). Physiol Entomol 23:202-207. https://doi.org/10.1046/j.1365-3032.1998.233086.x

Bostock RM, Thomas CS, Ogawa JM, Rice RE, Uyemoto JK (1987) Relationship of wound-induced peroxidase-activity to epicarp lesion development in maturing pistachio fruit. Phytopathology 77:275-282. https://doi.org/10.1094/Phyto-77-275

Bugg RL, Phatak SC, Dutcher JD (1990) Insects associated with coolseason cover crops in southern Georgia: implications for pest control in the truck-farm and pecan agroecosystems. Biol Agric Hortic 7:17-45. https://doi.org/10.1080/01448765.1990.11978494

Carmona DM, Douglas A, Landis F (1990) Influence of refuge habitats and cover crops on seasonal activity-density of ground beetles (Coleoptera: Carabidae) in field crops. Environ Entomol 28:11451153. https://doi.org/10.1093/ee/28.6.1145

da Silva PG, Daane KM (2014) Life history parameters of Chinavia hilaris (Hemiptera: Pentatomidae), a stink bug injurious to pistachios in California. J Econ Entomol 107:166-173. https://doi. org/10.1603/EC13272

da Silva PG, Daane KM, Korfanta NM, Kappagoda S, Halbig P, Beede RH, Holtz BA, Bentley WJ (1997) Biological control of hemipteran pests of pistachio: effect of orchard floor management practices on stink bugs and their natural enemies and on kernel necrosis. California Pistachio Industry, Annual Reports, Crop Year 1996-1997, Fresno CA, pp 54-59

Daane KM, Yokota GY, Krugner R, Steffan SA, Silva PG, Beede RH, Bentley WJ, Weinberger GB (2005) Large bugs damage pistachio nuts most severely during midseason. Calif Agric 59:95-102. https://doi.org/10.3733/ca.v059n02p95
Daane KM, Yokota GY, Bentley WJ, Weinberger G, Millar JG, Beede RH (2016) Stink bugs and leaffooted bugs. In: Ferguson L, Haviland DR (eds) Pistachio production manual. University of California, Agriculture and Natural Resources Publication no. 3545, Oakland, pp 186-196

Daane KM, Yokota GY, Wilson H (2019) Seasonal dynamics of the leaffooted bug Leptoglossus zonatus and its implications for control in almonds and pistachios. Insects 10:255-266. https://doi. org/10.3390/insects10080255

Demkovich M, Siegel JP, Higbee BS, Berenbaum MR (2015) Mechanism of resistance acquisition and potential associated fitness costs in Amyelois transitella (Lepidoptera: Pyralidae) exposed to pyrethroid insecticides. Environ Entomol 44:855-863. https://doi. org/10.1093/ee/nvv047

Duyck PF, Lavigne A, Vinatier F, Achard R, Okolle JN, Tixier P (2011) Addition of a new resource in agroecosystems: do cover crops alter the trophic positions of generalist predators? Basic Appl Ecol 12:47-55. https://doi.org/10.1016/j.baae.2010.11.009

Foster MA, Ruesink WG (1984) Influence of flowering weeds associated with reduced tillage in corn on a black cutworm (Lepidoptera: Noctuidae) parasitoid, Meleorus rubens (Nees von Esenbeck). Environ Entomol 13:664-668. https://doi.org/10. 1093/ee/13.3.664

Fox J, Weisberg S, Adler D, Bates D, Baud-Bovy G, Ellison S, Firth D, Friendly M, Gorjanc G, Graves S et al. (2016) Package 'car'. R Package Version. https://CRAN.R-project.org/package $=$ car

Geisseler D, Howarth WR (2016) Pistachio production in California. https://apps1.cdfa.ca.gov/FertilizerResearch/docs/Pistachio_ Production_CA.pdf. Accessed 22 Feb 2020

Gillespie MA, Gurr GM, Wratten SD (2016) Beyond nectar provision: the other resource requirements of parasitoid biological control agents. Entomol Exp Appl 159:207-221. https://doi.org/ 10.1111/eea. 12424

Godfrey LD, Leigh TF (1994) Alfalfa harvest strategy effect on Lygus bug (Hemiptera: Miridae) and insect predator population density: implications for use as trap crop in cotton. Environ Entomol 23:1106-1118. https://doi.org/10.1093/ee/23.5.1106

Graves S, Piepho HP, Selzer L, Dorai-Raj S (2019) multcompView: Visualizations of paired comparisons. R package version 0.1-8. https://CRAN.R-project.org/package=multcompView

Gurr GM, Wratten SD, Landis DA, You M (2017) Habitat management to suppress pest populations: progress and prospects. Annu Rev Entomol 62:91-109. https://doi.org/10.1146/annur ev-ento-031616-035050

Hokkanen HMT (1991) Trap cropping in pest management. Annu Rev Entomol 36:119-138. https://doi.org/10.1146/annurev.en. 36.010191.001003

Holtz BA (2002) Plant protection for pistachio. HortTechnology 12:626-632. https://doi.org/10.21273/HORTTECH.12.4.626

Hothorn T, Bretz F, Westfall P, Heiberger RM, Schuetzenmeister A, Scheibe S, Hothorn MT (2017) Package 'multcomp'. http://cran. statsfu.ca/web/packages/multcomp/multcomp

Huang M, Mai X, Li S, Situ J (1981) Biological control of citrus red mite, Panonychus citri (MEG.) in Guangdong Province. Proc Int Soc Citricult, pp 643-646

Jankevicius SI, De Almeida IL, Jankevicius JV, Cavazzana JR, Manzelio AM, De Souza W (1993) Axenic cultivation of trypanosomatids found in corn (Zea mays) and in phytophagous hemipterans (Leptoglossus zonatus Coreidae) and their experimental transmission. J Eukaryot Microbiol 40:576-581. https://doi.org/ 10.1111/j.1550-7408.1993.tb06110.x

Joyce AL, Barman AK, Doll D, Higbee BS (2019) Assessing feeding damage from two leaffooted bugs, Leptoglossus clypealis Heidemann and Leptoglossus zonatus (Dallas) (Hemiptera: Coreidae), on four almond varieties. Insects 10:333-343. https://doi.org/ 10.3390/insects 10100333 
Kamminga KL, Ames Herbert Jr D, Kuhar TP, Malone S, Doughty H (2009) Toxicity, feeding preference, and repellency associated with selected organic insecticides against Acrosternum hilare and Euschistus servus (Hemiptera: Pentatomidae). J Econ Entomol 102:1915-1921. https://doi.org/10.1603/029.102.0523

Kallsen C, Parfitt D, Maranto J, Holtz B (2009) New pistachio varieties show promise for California cultivation. Calif Agr 63:18 23. https://doi.org/10.3733/ca.v063n01p18

Khan ZR, Pickett JA, Berg JVD, Wadhams LJ, Woodcock CM (2000) Exploiting chemical ecology and species diversity: stem borer and striga control for maize and sorghum in Africa. Pest Manag Sci 56:957-962. https://doi.org/10.1002/1526-4998(200011)56: 11\%3c957:AID-PS236\%3e3.0.CO;2-T

Koch RL, Pezzini DT, Michel AP, Hunt TE (2017) Identification, biology, impacts, and management of stink bugs (Hemiptera: Heteroptera: Pentatomidae) of soybean and corn in the Midwestern United States. J Integr Pest Manag 8:11-22. https://doi. org/10.1093/jipm/pmx004

Khrimian A, Zhang A, Weber DC, Ho HY, Aldrich JR, Vermillion KE, Siegler MA, Shirali S, Guzman F, Leskey TC (2014) Discovery of the aggregation pheromone of the brown marmorated stink bug (Halyomorpha halys) through the creation of stereoisomeric libraries of 1-bisabolen-3-ols. J Nat Prod 77:17081717. https://doi.org/10.1021/np5003753

Langellotto GA, Denno RF (2004) Responses of invertebrate natural enemies to complex-structured habitats: a meta-analytical synthesis. Oecologia 139:1-10. https://doi.org/10.1007/ s00442-004-1497-3

Length R (2020) emmeans: Estimated marginal means, aka leastsquares means. R package version 1.4.6. https://CRAN.R-proje ct.org $/$ package $=$ emmeans

Leskey TC, Hogmire HW (2005) Monitoring stink bugs (Hemiptera: Pentatomidae) in mid-Atlantic apple and peach orchards. J Econ Entomol 98:143-153. https://doi.org/10.1603/0022-0493-98.1. 143

Long R, Corbett A, Lamb C, Reberg-Horton C, Chandler J, Stimmann M (1998) Beneficial insects move from flowering plants to nearby crops. Calif Agr 52:23-26. https://doi.org/10.3733/ ca.v052n05p23

Marino PC, Landis DA (1996) Effect of landscape structure on parasitoid diversity and parasitism in agroecosystems. Ecol Appl 6:276-284. https://doi.org/10.2307/2269571

Majumdar A, Price M (2019) Major lessons from large-scale trap cropping demonstrations for pest reduction in vegetables. Ann Entomol Soc Am 112:298-301. https://doi.org/10.1093/aesa/say059

McPherson RM, Newsom LD, Farthing BF (1979) Evaluation of four stink bug species from three genera affecting soybean yield and quality in Louisiana. J Econ Entomol 72:188-194. https://doi.org/ 10.1093/jee/72.2.188

Mensah RK, Khan M (1997) Use of Medicago sativa (L.) interplantings trap crops in the management of the green mirid, Creontiades dilutes (Stål) in commercial cotton in Australia. Int J Pest Manag 43:197-202. https://doi.org/10.1080/096708797228681

Michailides TJ, Rice RE, Ogawa JM (1987) Succesion and signficance of serveral hemipterans attaching a pistachio orchard. J Econ Entomol 80:398-406. https://doi.org/10.1093/jee/80.2.398

Michailides TJ (1989) The "Achilles heel" of pistachio fruit. Calif Agric 43:10-11

Mitchell ER, Ho GG, Johanowicz D (2000) Management of diamondback moth (Lepidoptera: Plutellidae) in cabbage using collard as a trap crop. HortScience 35:875-879

Morehead JA, Kuhar TP (2017) Efficacy of organically approved insecticides against brown marmorated stink bug, Halyomorpha halys and other stink bugs. J Pest Sci 90:1277-1285. https://doi.org/10. 1007/s10340-017-0879-3
Morrison WR III, Cullum JP, Leskey TC (2015) Evaluation of trap designs and deployment strategies for capturing Halyomorpha halys (Hemiptera: Pentatomidae). J Econ Entomol 108:16831692. https://doi.org/10.1093/jee/tov159

Morrison WR III, Mathews CR, Leskey TC (2016) Frequency, efficiency, and physical characteristics of predation by generalist predators of brown marmorated stink bug (Hemiptera: Pentatomidae) eggs. Biol Control 97:120-130. https://doi.org/10.1016/j. biocontrol.2016.03.008

Morrison WR III, Bryant AN, Poling B, Quinn NF, Leskey TC (2017) Predation of Halyomorpha halys (Hemiptera: Pentatomidae) from web-building spiders associated with anthropogenic dwellings. J Insect Behav 30:70-85. https://doi.org/10.1007/ s10905-017-9599-Z

Ogburn EC, Walgenbach JF (2019) Effects of insecticides used in organic agriculture on Anastatus reduvii (Hymenoptera: Eupelmidae) and Telenomus podisi (Hymenoptera: Scelionidae), egg parasitoids of pestivorous stink bugs. J Econ Entomol 112:108-114. https://doi.org/10.1093/jee/toy340

Pacheco R, Vasconcelos HL (2012) Habitat diversity enhances ant diversity in a naturally heterogeneous Brazilian landscape. Biodivers Conserv 21:797-809. https://doi.org/10.1007/ s10531-011-0221-y

Pote JM, Nielsen AL (2017) Life stage specific predation of Halyomorpha halys (Stål) by generalist predators. Biol Control 114:1-7. https://doi.org/10.1016/j.biocontrol.2017.07.007

Purcell M (1991) Welter SC (1991) Effect of Calocoris norvegicus (Hemiptera: Miridae) on pistachio yields. J Econ Entomol 84:114-119. https://doi.org/10.1093/jee/84.1.114

R Core Team (2020) R: a language and environment for statistical computing. R Foundation for Statistical Computing, Vienna, Austria. https://www.R-project.org/

RStudio Team (2016) RStudio: integrated development for R. RStudio, PBC, Boston, MA. http://www.rstudio.com/

Rea JH, Wratten SD, Sedcole R, Cameron PJ, Davis SI, Chapman RB (2002) Trap cropping to manage green vegetable bug Nezara viridula (L.) (Heteroptera: Pentatomidae) in sweet corn in New Zealand. Agricul Forest Entomol 4:101-107. https://doi.org/10. 1046/j.1461-9563.2002.00130.x

Ribeiro AV, Holle SG, Hutchison WD, Koch RL (2021) Lethal and sublethal effects of conventional and organic insecticides on the parasitoid Trissolcus japonicus, a biological control agent for Halyomorpha halys. Front Insect Sci 1:685755. https://doi.org/ 10.3389/finsc.2021.685755

Shelton AM, Badenes-Perez FR (2006) Concepts and applications of trap cropping in pest management. Annu Rev Entomol 51:285308. https://doi.org/10.1146/annurev.ento.51.110104.150959

Soergel DC, Ostiguy N, Fleischer SJ, Troyer RR, Rajotte EG, Krawczyk G (2015) Sunflower as a potential trap crop of Halyomorpha halys (Hemiptera: Pentatomidae) in pepper fields. Environ Entomol 44:1581-1589. https://doi.org/10.1093/ee/nvv136

Stahl JM, Scaccini D, Pozzebon A, Daane KM (2020) Comparing the feeding damage of the invasive brown marmorated stink bug to a native stink bug and leaffooted bug on California pistachios. Insects 11:688-701. https://doi.org/10.3390/insects11100688

Stern VM, van den Bosch R, Leigh TF (1964) Strip cutting alfalfa for Lygus bug control. Calif Agric 18:4-6

Thurston HD (1991) Sustainable practices for plant disease management in traditional farming systems. Westview, Boulder, p 279

Tillman PG, Aldrich JR, Khrimian A, Cottrell TE (2010) Pheromone attraction and cross-attraction of Nezara, Acrosternum, and Euschistus spp. stink bugs (Heteroptera: Pentatomidae) in the field. Environ Entomol 39:610-617

Tillman PG (2011) Natural biological control of stink bug (Heteroptera: Pentatomidae) eggs in corn, peanut, and cotton farmscapes 
in Georgia. Environ Entomol 40:303-314. https://doi.org/10.1603/ EN09114

Todd JW (1989) Ecology and behavior of Nezara viridula. Annu Rev Entomol 34:273-292. https://doi.org/10.1146/annurev.en.34. 010189.001421

Tomaseto AF, Marques RN, Fereres A et al (2019) Orange jasmine as a trap crop to control Diaphorina citri. Sci Rep 9:2070-2081. https://doi.org/10.1038/s41598-019-38597-5

Toscano NC, Stern VM (1976) Cotton yield and quality loss caused by various levels of stink bug infestations. J Econ Entomol 69:53-56. https://doi.org/10.1093/jee/69.1.53

Velasco LRI, Walter GH (1993) Potential of host-switching in Nezara viridula (Hemiptera: Pentatomidae) to enhance survival and reproduction. Environ Entomol 22:326-333. https://doi.org/10. 1093/ee/22.2.326

Wilson H, Maccaro JJ, Daane KM (2020a) Optimizing trap characteristics to monitor the leaffooted bug Leptoglossus zonatus
(Heteroptera: Coreidae) in orchards. Insects 11:358-367. https:// doi.org/10.3390/insects11060358

Wilson H, Yazdani AS, Daane KM (2020b) Influence of riparian habitat and ground covers on three cornered alfalfa hopper (Hemiptera: Membracidae) populations in vineyards. J Econ Entomol 113:2354-2361. https://doi.org/10.1093/jee/toaa151

Zalom FG, Smilanick JM, Ehler LE (1997) Fruit damage by stink bugs (Hemiptera: Pentatomidae) in bush-type tomatoes. J Econ Entomol 90:1300-1306. https://doi.org/10.1093/jee/90.5.1300

Publisher's Note Springer Nature remains neutral with regard to jurisdictional claims in published maps and institutional affiliations. 